\title{
8.4 Комплексна оцінка візуальних якостей міського середовища як крок до його системної гармонізації
}

Архітектура - мистецтво і наука проектувати і будувати будівлі і споруди (включаючи їх комплекси), а також сама сукупність будівель і споруд, які створюють просторове середовище для життя і діяльності людини. Архітектура формує матеріально організоване середовище, необхідне людям для їх життя і діяльності, відповідно до їх спрямувань, технічних можливостей і естетичних уподобань.

Згідно з цим визначенням, архітектуру можна розглядати одночасно як науку і мистецтво формування антропогенних просторів.

За призначенням антропогенні простори можна розділити на три категорії:

1. простори першого типу, основне призначення яких - створення максимально комфортних умов для людей, що знаходяться в просторі. Історично архітектура почала формувати саме простори першого типу - від поселень первісних людей до міст регулярного планування XVII - XVIII ст.;

2. на відміну від перших, простори другого типу в основному забезпечують функціонування просторів першого типу (здобич, виробництво, складування сировини, напівфабрикатів і продукції, розміщення транспортних мереж, транзитні зони. Рівень їх комфортності безпосередньо для людини росте із збільшенням технічного прогресу, проте цей комфорт створюється виключно в цілях підвищення працездатності і забезпечення норм безпеки.

Пріоритетним в таких просторах є забезпечення оптимальної технологічної схеми, і людина в них розглядається як частина цієї системи. Простори другого типу повною мірою виділилися як самостійні утворення за часів Першої Промислової Революції у XVIII ст.;

3. простори-межі - найбільш історично "молоді" утворення, що призначені забезпечувати ситуацію переходу людини і ресурсів з просторів першого типу в другій і назад. Також до просторів третього типу можна віднести "буферні зони" між антропогенними і природними просторами. Стан людини в них можна 
охарактеризувати як ініціацію, перехід з одного стану в інше, і призначення простору-межі - зробити такий перехід максимально безпечним.

Залежно від кліматичних, демографічних, культурних, соціальних, економічних, політичних i комплексу інших чинників люди формують різні поєднання цих просторів. Оскільки міняються вищезгадані чинники, остільки ці простори, відповідаючи цим змінам, народжуються, розвиваються, міняють свій тип. Але при порушенні гармонійного зв'язку з людиною (який ми розглянемо детальніше далі) простори усіх трьох типів перестають виконувати своє призначення.

При втраті зв'язку з іншими антропогенними просторами такі ділянки, що деградували (або природним чином, або із-за людей) повертаються до природного стану. Якщо ж простір, що деградував, неможливо вилучити 3 тканини взаємозв'язаних просторів (у місті така тканина особливо щільна) утворюється "сліпа пляма", "діра" [519]. Потрапивши в таке середовище, люди його прагнуть покинути із-за фізичного i психологічного дискомфорту. Як наслідок, зростає функціональне навантаження на безпосередньо пов'язані 3 "дірою" простори, що, у свою чергу, може привести до їх деградації зокрема.

Найбільш щільний і різноманітний малюнок поєднань просторів усіх трьох типів формується в розвинених урбаністичних конгломераціях, що об'єднують різні функції (промислове виробництво, транспортний вузол, соціальне обслуговування населення), і формуються в течії декількох історичних етапів. Мультифункціональность дає "горизонтальний" розвиток складної мережі просторів і проблематику їх спільного прогресу, оскільки зміна однієї ділянки автоматично чинить вплив на суміжні з ним. Історична перспектива формує "вертикаль" - яка визначає пріоритети подальшого розвитку кожного з просторів i ïx комплексу iз збереженням або формуванням наново унікального "духу місця", властивого як конкретним районам, так і місту в цілому.

I "горизонтальний" i "вертикальний" розвиток міських просторів можна відстежувати, спираючись на різні їх функції і відповідно вибираючи точку зору (архітектора, урбаніста, економіста, політолога, соціолога, психолога і так далі). 
Проте простежується тенденція до розгляду громадських міських просторів як ресурсу для забезпечення руху "потоків" і "мас" (людей, транспорту, ресурсів і тому подібне).

Недостатня доля погляду теоретичних дослідників і архітекторів, що практикують, на міські простори з точки зору їх мешканців і споживачів нині привів до ряду негативних наслідків :

1. погіршення якостей просторів першого типу з їх подальшою зміною функції у бік просторів другого типу або деградацією;

2. зростання кількості зон, що деградували, і зменшення кількості просторів третього типу.

Як загальний ітог - порушення щільності міської тканини, що, як було вказано вище, веде до погіршення функціонування усіх міських просторів в цілому.

Ці проблеми актуальні як для світової архітектури взагалі [520], так і для архітектури міст сучасної України зокрема [521]. Сучасне суспільство вимагає поліпшення зв'язку між пересічним громадянином і простором, у якому він живе. Єдиним шляхом відновити цей зв'язок стане додаткове дослідження перш за все візуальних якостей середовища, як пріоритетних при взаємодії із простором пересічної людини. Досліджуючи фізіологічний, психологічний, соціальноестетичний вплив візуальної частини міського середовища на людину, можна вивести закономірності створення позитивного резонансу між простором та людиною за допомогою візуальних чинників та рекомендувати конкретні проектні рішення для візуальної гармонізації як тих міських просторів, що вже існують, так і для тих, що проектуються.

Наукова новизна використання комплексної оцінки візуальних якостей міського середовища під час предпроєктних досліджень полягає у тому, що вона дозволяє:

- $\quad$ оцінити головні фактори взаємодії у рамках системи «людинаміський простір» 3 точки зору фізіології [522], психічних та соціокультурних 
уподобань саме людей (а не з боку ефективності руху транспорту, дії виробничих процесів тощо);

- об'єктивно дослідити вищеназвані фактори за допомогою методу окулографії, який до цього не використовивався для оцінювання якостей міського простору і об'єктів у ньому;

- $\quad$ на основі найбільш ефективних методів дослідження візуальних якостей міського середовища $[523,524,525,526]$ дати комплексну оцінку його якостей, які впливають на привабливість простору для людей і дозволяють дати рекомендації по його розвитку та впливу на пов’язані із ним зони тканини міста;

- $\quad$ доповнити традиційну методику предпроєктного аналізу новими методами [527, 528], які дозволять висувати більш ефективні та привабливі 3 точки зору людини проектні пропозиції;

- $\quad$ встановити позитивний двосторонній зв'язок між людиною i простором, що, за висунутою теорією резонансу [529], дозволяє будь-якому міському простору використовуватися людьми найбільш повно і різноманітно. 